\title{
Editorial
}

\section{Editorial: Federal Restrictions on Gun Research Should Be Lifted}

\author{
Seth S. Leopold MD
}

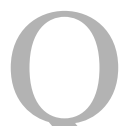

uestion: What do Parkinson's disease, sepsis, liver disease, gun violence, traffic accidents, poisoning, and nephritis have in common?

Answer: They all kill about 30,000 people a year in the United States (stated another way, about 10 deaths per 100,000 in the population).

Question: What do those conditions not have in common?

Answer: Federal research funding.

From 2004 to 2015, federal funding for research about firearm-related

The author certifies that neither he, nor any members of his immediate family, have any commercial associations (such as consultancies, stock ownership, equity interest, patent/licensing arrangements, etc) that might pose a conflict of interest in connection with the submitted article. All ICMJE Conflict of Interest Forms for authors and Clinical Orthopaedics and Related Research ${ }^{\mathbb{R}}$ editors and board members are on file with the publication and can be viewed on request.

The opinions expressed are those of the writers, and do not reflect the opinion or policy of $C O R R^{\circledR}$ or The Association of Bone and Joint Surgeons ${ }^{\circledR}$.

\section{S. S. Leopold MD ( $\square)$}

Clinical Orthopaedics and Related

Research®, 1600 Spruce St.,

Philadelphia, PA 19103, USA

e-mail: sleopold@clinorthop.org fatalities is only $1.6 \%$ of what one would predict it should be, based on the number of gun-related deaths [15]. Sepsis, for example, which causes about the same number of deaths, received over USD 3 billion during that time, compared to only USD 22 million for gun research [15]. In fact, looking only at fatalities from different conditions (as these statistics do) underestimates both morbidity and costs associated with gun-related harm, which disproportionately affects the young, robbing them of many productive years of work. Gun-related harm imposes heavy burdens both on the US healthcare system [5] and society at large [16].

That needs to change. The federal government's scientific-funding agencies-specifically the CDC and the NIH-need to reverse a two-decadeslong neglect of a public-health problem that kills tens of thousands of people per year, and injures far more than that.

Neglect actually is the wrong word. The disproportion between funding for and harm caused by guns was entirely intentional, and explicitly legislative: Since 1997, the CDC has been constrained by an amendment to that year's Omnibus Consolidated Appropriations Act, which states that "none of the funds made available for injury prevention and control at the Centers for Disease Control and Prevention may be used to advocate or promote gun control" [18]. Although the NIH was not explicitly restricted in that way until 2012 [17], it had generally followed suit, and only recently resumed funding work on this topic [11], and only on a small scale [14]. The CDC still does not [14], and has generally interpreted the vague language of the appropriations act to mean that no research on gun violence of any sort can be funded, and indeed, it has funded none [7].

While one can speculate about the reasons for the slight interagency difference in interpreting what has come to be called the Dickey Amendment-which has persisted in every appropriations bill since 1997-it is well worth noting that its author, Rep. Jay Dickey (a now-retired member of Congress from Arkansas) has had a change of heart. He recently suggested that the ban he sponsored 20 years ago should be lifted [2, 3]. Although President Barack Obama issued a memorandum to his Secretary of Health and Human Services in 2013 to lift the restrictions [13], the fact is that Congress holds the purse strings here, and I suspect this fact is well known 


\section{Editorial}

both to the CDC and the NIH. After all, it was a CDC-funded study that sparked the firestorm leading to the Dickey Amendment [1, 8]. And to make sure the point was not missed, that year Congress cut the CDC's budget by precisely the amount it had spent the previous year on research related to firearms. The funding later was restored in joint conference committee, but it was earmarked for traumatic brain injury [7]. The point had been made.

It is time to change our approach, but change of this sort is difficult, largely because of lingering sensitivities on both sides of the debate. Perhaps we might find common cause on themes that most citizens agree upon. For example, a great deal has been made lately about the importance of reducing healthcare disparities. If that indeed is a priority, it's hard to find a better topic with which to start than gun violence. Black men die from gunshot wounds at three times the rate of the general population (and young black men at seven times that rate) [10]. If not healthcare disparities, then perhaps a focus on protecting children from potentially preventable harm associated with firearms-accidents and suicides-could be an uncontroversial first step. Or perhaps we can be more ambitious, and recognize that if a new germ were killing citizens at this rate, we would properly call it an epidemic, and adjust research priorities accordingly. Research about accidents on our motorways has made our roads and vehicles safer. Research on gun violence can do likewise.

I am not naïve. This issue is political at least as much as it is scientific. The Dickey Amendment was a response by a Republican member of Congress to a study [8] that some believed had a political agenda favoring gun control. By contrast, in the face of the federal restriction, left-leaning localities have pushed back; for example, the Seattle city council has stepped in to fill with dollars what it perceives to be a research void on this important topic [12]. I am not suggesting that orthopaedic surgeons march in the streets to ban handguns. But the federal government's grant-funding agencies seem more capable of balancing issues of bias (and politics) than do localities and special-interest groups, and the quality of the research is likely to be better-and the scope of the work more comprehensive, given the depth of the pockets-if the NIH and the CDC get involved. Besides, given the magnitude of the publichealth problem here, it is only right that federal funding agencies take the lead.
Orthopaedic surgeons and scientists with connections either to those federal agencies or to representatives in Washington should make these points to them. The Political Action Committee of the American Association of Orthopaedic Surgeons should follow the American Medical Association's lead [6] and lobby the federal government on this issue; given that surgeons far more than internists will be the ones caring for patients injured by guns, it seems incumbent on our subspecialty's lobbying arm to advocate or our patients in this way. The US Department of Veterans Affairs has a role to play here, since more than twice as many gun deaths are suicides than homicides, and our nation's veterans are at special risk of suicide. The VA does support of research on the topic [19]; no doubt it would entertain further grant proposals on topics germane to its beneficiaries. Orthopaedic surgeons willing to work alongside social scientists may find the National Science Foundation a more-willing supporter now [9] than it was even a few years ago [4]. One way or another, orthopaedic clinicianscientists must find ways to ask important questions about gun violence, find support, and get those questions answered.

Even Rep. Dickey feels this way now. Although he came around some 


\section{Editorial}

20 years too late, I can say it no better than did Rep. Dickey: "Doing nothing is no longer an acceptable solution" [2].

Acknowledgment I would like to thank Clare M. Rimnac PhD for her thoughtful suggestions, which improved this essay.

\section{References}

1. Aleccia J. Seattle scientist still pushes to lift funding ban on gunviolence studies. Available at: http:// www.seattletimes.com/seattle-news/ health/seattle-scientist-still-lobbiesto-lift-funding-ban-on-gun-violencestudies/. Accessed March 10, 2017.

2. Dickey J. Gun violence scientific research needed. Letter to US Rep. Mike Thomson, Chair of the House Gun Violence Prevention Task Force. Available at: http://mikethompson.house.gov/newsroom/press-releases/ thompson-former-rep-jay-dickey-callsto-end-federal-ban-on-gun-violence. Accessed March 10, 2017.

3. Dickey J, Rosenberg M. How to protect gun rights while reducing the toll of gun violence. Available at: https://www.washingtonpost.com/ opinions/time-for-collaboration-ongun-research/2015/12/25/f989cd1aa819-11e5-bff5-905b92f5f94b_story. html?utm_term=.0f9ce0c496ea. Accessed March 10, 2017.

4. Frankel TC. Why the CDC still isn't researching gun violence, despite the ban being lifted two years ago. Available at: https://www.washingtonpost.com/news/storyline/wp/2015/01/ 14/why-the-cdc-still-isnt-researchinggun-violence-despite-the-ban-beinglifted-two-years-ago/?utm_term=.39 33d7f03973. Accessed March 14, 2017.

5. Howell E, Bieler S, Anderson N. State variation in hospital use and cost of firearm assault injury, 2010. Available at: http://www.urban.org/ sites/default/files/alfresco/publicationpdfs/413210-State-Variation-in-Hospital-Use-and-Cost-of-Firearm-AssaultInjury-.PDF. Accessed March 14, 2017.

6. Johnson SR. AMA asks for end to ban on gun research funding. Available at: http://www.modernhealthcare. com/article/20160614/NEWS/160619 952. Accessed March 10, 2017.

7. Kellermann AL, Rivara FP. Silencing the silence on gun research. JAMA. 2013;309:549-550.

8. Kellermann AL, Rivara FP, Rushforth NB, Banton JG, Reay DT, Francisco JT, Locci AB, Prodzinski J, Hackman BB, Somes G. Gun ownership as a risk factor for homicide in the home. $N$ Engl $\mathrm{J}$ Med. 1993;329:1084-1091.

9. Margetta R. Analyzing how gun violence affects high-risk populations. Available at: https://www.nsf. gov/discoveries/disc_summ.jsp?cntn_ id $=139074 \&$ org $=$ NSF \& from $=$ news. Accessed March 17, 2017.

10. National Center for Health Statistics. Health, United States, 2015: With special feature on racial and ethnic health disparities. Available at: https:// www.cdc.gov/nchs/hus/citation.htm. Accessed March 10, 2017.
11. National Institutes of Health. NIH calls for research projects examining violence-Particular consideration to be given for firearm violence. Available at: https://www.nih.gov/ news-events/news-releases/nih-callsresearch-projects-examining-violence. Accessed March 14, 2017.

12. NBC News. Chiding Congress: Seattle first city to fund gun violence research. Available at: http://vitals. nbcnews.com/_news/2013/03/22/17 405241-chiding-congress-seattle-firstcity-to-fund-gun-violence-research. Accessed March 10, 2017.

13. Obama B. Presidential memorandum - Engaging in public health research on the causes and prevention of gun violence. Available at: https://obamawhitehouse.archives.gov/the-pressoffice/2013/01/16/presidential-memorandum-engaging-public-health-research-causes-and-preve. Accessed March 10, 2017.

14. Rubin R. Tale of 2 agencies: CDC avoids gun violence research but NIH funds it. JAMA. 2016;315: 1689-1692.

15. Stark DE, Shah NH. Funding and publication of research on gun violence and other leading causes of death. JAMA. 2017;317:84-85.

16. The Future of Children. Children, youth, and gun violence: Analysis (executive summary). The Future of Children. 2002;12:1-4.

17. United States Congress. Consolidated Appropriations Act, 2012. Available at: https://www.congress. gov/112/plaws/publ74/PLAW-112pub 174.pdf. Accessed March 10, 2017. 
18. United States Congress. Omnibus Consolidated Appropriations Act, 1997. Available at: https://www.gpo. gov/fdsys/pkg/PLAW-104publ208/
pdf/PLAW-104publ208.pdf. Accessed March 10, 2017.

19. U.S. Department of Veterans Affairs, Office of Research and
Development. VA research on suicide prevention. Available at: https:// www.research.va.gov/topics/suicide. cfm. Accessed March 14, 2017. 